\title{
$\begin{array}{lllllllllllllllll}\mathbf{R} & \mathbf{O} & \mathrm{Z} & \mathbf{P} & \mathbf{R} & \mathbf{A} & \mathbf{W} & \mathbf{Y} & \text { I } & \text { A } & \mathbf{R} & \mathbf{T} & \mathbf{Y} & \mathrm{K} & \mathbf{U} & \mathbf{L} & \mathbf{Y}\end{array}$
}

ks. Ginter Dzierżon

Ius Matrimoniale

28 (2017) $\mathrm{nr} 3$

DOI:10.21697/im.2017.28.3.01

Wydział Prawa Kanonicznego UKSW

\section{Forma wyrażenia zgody małżeńskiej określona w kan. 1104 \$1-2 KPK}

\section{Wstęp}

W kanonicznym porządku prawnym przyczyną sprawczą małżeństwa jest zgoda małżeńska (kan. 1057 \$2 KPK). Należy jednak zauważyć, iż zapis przywołanego kanonu ma charakter generalny. Przedmiotem uwagi prawodawcy bowiem w tej regulacji, co z punktu widzenia legislacyjnego jest zupełnie zrozumiałe, nie stały się kwestie szczegółowe, w tym również problem formy wyrażenia konsensu małżeńskiego. Do tego ostatniego wątku odniósł się on w kan. 1104 \$1-2 KPK postanawiając: „Do ważnego zawarcia małżeństwa konieczne jest, by nupturienci byli równocześnie obecni, bądź osobiście, bądź też przez pełnomocnika (\$1). Zgodę małżeńską nupturienci powinni wyrazić słowami, a gdy nie mogą wyrazić równoznacznymi znakami (\$2)”. Regulacja ta stanie się przedmiotem zainteresowania w niniejszym opracowaniu. Ze wstępnej analizy treści tego kanonu wynika, iż należałoby wyróżnić dwa zasadnicze obszary tematyczne: kwestia konieczności równoczesnej obecności nupturientów oraz problem sposobów wyrażenia zgody małżeńskiej. 


\section{Konieczność równoczesnej obecności nupturientów (kan. $1104 \$ 1 \mathrm{KPK}$ )}

Komentatorzy interpretując kan. $1104 \$ 1$ KPK zgodnie utrzymują, iż do ważności małżeństwa nupturienci powinni być równocześnie obecni: osobiście lub przez pełnomocnika (kan. $1105 \$ 4 \mathrm{KPK})^{1}$. Z podobnym zapisem spotykamy się w kan. 837 KKKW. Przy tym należy zauważyć, że w prawie wschodnim konieczność obecności stron jest wzmocniona wymogiem obligującym strony do otrzymania kapłańskiego błogosławieństwa ${ }^{2}$.

Na marginesie należy dodać, iż w późnym prawie rzymskim, a także w prawie germańskim nie zezwalano na zawieranie małżeństwa przez pełnomocnika. Taką możliwość wprowadzono dopiero w prawie justyniańskim; w prawie kościelnym natomiast takie rozwiązanie przyjęto w epoce kanonistyki klasycznej ${ }^{3}$. W trakcie prac nad rewizją Kodeksu z 1917 r. konsultorzy sugerowali zniesienie tej instytucji. W nowej kodyfikacji nie wprowadzono tej sugestii w życie, uzasadniając tę decyzję zjawiskiem dużej migracji ludności we współczesnym świecie 4 .

Kanoniści w swych opracowaniach podają różnego rodzaju argumenty uzasadniające funkcjonowanie takiego ustalenia normatywnego. Odnosząc się do zapisu kan. $1104 \$ 1$ KPK Sabbarese podkreślił, że obecność kontrahentów jest gwarantem ważności wyrażenia zgody małżeńskiej. Gwarancja, o której mowa bezpośrednio dotyczy ważności matrimonium in fieri; pośrednio natomiast odnosi się do

1 Por. F. Aznar Gíl, Derecho matrimonial canónico, t. 2, Salamanca 2002, s. 264265; F. Bersini, Il diritto canonico matrimoniale, Torino 1994, s. 138; P. J.VILAdrich, Konsens małżeński, tłum. S. ŚwiACZny, Warszawa 2002, s. 456.

2 Por. D. Salachas, Commento al. can 837 CCEO, w: Commento al Codice dei Canoni delle Chiese Orientali, red. P. V.Pinto, Città del Vaticano 2001, s. 717.

3 Por. R. Sевотт, Das neue kirchliche Eherecht, Franfurt am Main 2005, s. 106; J. Fornés, Derecho matrimonial canónico, Madrid 2008, s. 140.

4 Por. Communicationes 9 (1977), s. 377; R. Sевотт, Das neue..., dz. cyt., s. 106; J. Fornés, Derecho matrimonial..., dz. cyt., s. 141. 
matrimonium in facto esse ${ }^{5}$. W ten nurt interpretacyjny organicznie wpisują się podglądy Pedro Juana Viladricha i Francesco Bersiniego. Pierwszy z nich uważa, że wymóg skodyfikowany w kan. $1104 \$ 1$ KPK jest gwarantem jedności konstytutywnego aktu jakim jest konsens małżeński ${ }^{6}$. Bersini z kolei stwierdził, iż małżeński konsens uzyskuje skuteczność nie w wyniku wyrażenia go przez jednego z kontrahentów, ale równocześnie obu kontrahentów ${ }^{7}$. Małżeństwa bowiem, dodają Klaus Lüdicke i Luigi Chiappetta, nie tworzą przecież dwie zgody, lecz jedna zgoda stron ${ }^{8}$. Lüdicke wyjaśnił też tę kwestię poglądowo. Wskazał on, iż związek byłby nieważny, gdyby jeden z nupturientów zawarł go przed urzędnikiem cywilnym; drugi natomiast wobec duchownego'.

Według kanonistów, do wypełnienia tego wymogu zobowiązani są nie tylko katolicy, ale także akatolicy zawierający związki małżeńskie z katolikami (kan. 1059 KPK) ${ }^{10}$. Twierdzenie to znajduje umocowanie w opublikowanej w dniu 15 lipca 1949 r. pozytywnej odpowiedzi Kongregacji Świętego Officjum z 18 maja 1949 r., na pytanie: Czy kan. $1088 \$ 1$ CIC/17 należy aplikować także do małżeństw akatolików ochrzczonych?, którą zatwierdził papież Pius XII w dniu 26 czerwca 1949 r. $^{11}$. Wyjaśniając ten zapis Kongregacja ta w kolejnej odpowiedzi z 15 lipca 1949 r. precyzyjniej stwierdziła, iż w małżeństwach,

5 Por. L. SABbarese, Il matrimonio canonico nell'ordine della natura e della grazia, Roma 2016, s. 288.

6 Por. P. J. Viladrich, Konsens małżeński, dz. cyt., s. 456.

7 Por. F. Bersini, Il diritto canonico..., dz. cyt., s. 138; G. Boni, La manifestazione del consenso matrimoniale e il matrimonio per procura e per interprete, w: P. A. BONNET, C. Gullo (red.), Diritto matrimoniale, Città del Vaticano 2007, s. 608.

8 Por. K. Lüdicke, Heiligungsamt: Ehe, w: K. Lüdicke (red.), Münsterischer Kommentar zum Codex Iuris Canonici, t. 1, Essen 1985, ad. 1104, 3; L. Chiappetta, Il matrimonio nella nuova legislazione canonica e concordatoria, Roma 1990, s. 256.

9 Por. K. LüDICKe, Heiligungsamt, dz. cyt., ad. 1104, 2.

10 Por. J. Hendriks, Diritto matrimoniale. Commento ai canoni 1055-1165, Milano 1998, s. 220.

11 Por. Suprema Sacra Congregatio S. Officil, Responsa-18 V 1949, AAS 41 (1949), s. 427: „Utrum praesrciptum can. $1088 \$ 1$ applicetur etiam matrimoniis acatholicorum baptizatorum. Affirmative”. 
w których przynajmniej jedna strona byłaby ochrzczona zostałyby one zawarte nieważnie, jeśli jedna $\mathrm{z}$ nich byłaby nieobecna ${ }^{12}$. Komentując tę odpowiedź Stolicy Apostolskiej trafnie zauważył Lüdicke, iż walor tego wymogu jest inny w odniesieniu do małżeństwa ochrzczonych, które ma charakter sakramentalny, inny natomiast w odniesieniu do małżeństwa ochrzczonego z nieochrzczonym, które nie ma takiego charakteru. W pierwszym przypadku wynika on z prawa Bożego, w drugim przypadku natomiast wypływa z prawa pozytywnego ${ }^{13}$.

W opracowaniach niemieckich wskazuje się, iż zasadniczym powodem podjęcia takiej decyzji przez Dykasterię Kurii Rzymskiej była pewna praktyka stosowana podczas II wojny światowej. Mianowicie, na forum cywilnym za ważne uznawano związki, w których żołnierz wyrażał zgodę przed przedstawicielem wojskowym, po czym przesyłano do miejsca pobytu kobiety do podpisania stosowny dokument. Po tym fakcie wyrażała ona zgodę wobec urzędnika państwowego i dwóch świadków ${ }^{14}$. Z kanonicznego punktu widzenia, jak zauważył Reinhold Sebott, problemem było to, że takie związki małżeńskie były nieważne dla tych, którzy byli zobowiązani do zawarcia małżeństwa w formie kanonicznej ${ }^{15}$.

\section{Sposoby wyrażenia zgody małżeńskiej (kan. $1104 \$ 2$ KPK)}

W kan. $1104 \$ 2$ KPK ustawodawca odnosząc się do kwestii sposobów wyrażenia zgody małżeńskiej zawarł zasadę generalną związaną z wyrażeniem konsensu za pomocą słów oraz wyjątek od tego

\footnotetext{
12 Por. Suprema Sacra Congregatio S. Officil, Responsa-15 VII 1949, w: Leges Ecclesiae, t. 2, kol. 2615. Szerzej na ten temat zob. L. Sabbarese, Il matrimonio..., dz. cyt., s. 288.

13 Por. K. LüdICKe, Heiligungsamt..., dz. cyt., ad. 1104, 3.

14 Por. R. Sebott, Das neue..., dz. cyt., s. 106; J. Fornés, Derecho matrimonial..., dz. cyt., s. 140; R. Althaus, J. Prader, J.F. Reinhard, Das kirchiliches Eherecht in der seelsorgeriscger Praxis, Essen 2014, s. 132.

15 Por. R. Sebott, Das neue..., dz. cyt., s. 106; J. Fornés, Derecho matrimonial..., dz. cyt., s. 140 .
} 
pryncypium, w którym nie wykluczono w określonych sytuacjach możliwości zawarcia małżeństwa za pomocą równoznacznych znaków.

\subsection{Zasada generalna}

Zgodnie z kan. $1104 \$ 2$ KPK nupturienci powinni wyrazić zgodę słowami. W „Słowniku języka polskiego PWN” pod terminem „słowo” rozumie się m. in. „zespół dźwięków [...] odpowiadających danemu pojęciu", a także wypowiedź ustną ${ }^{16}$.

$\mathrm{W}$ omawianym zapisie prawodawca mówi o słowach. Zwieranie związku powinno się odbyć zatem zgodnie z sekwencją słów zamieszczonych w obrzędach zawierania małżeństwa, a więc według z przepisów liturgicznych. $W$ „Obrzędach sakramentu małżeństwa dostosowanych do zwyczajów diecezji polskich" nupturienci powinni zawrzeć związek małżeński według następującej formuły: „Ja N. biorę Ciebie, N. za żonę (męża) i ślubuję Ci, miłość, wierność, i uczciwość małżeńską oraz że Cię nie opuszczę aż do śmierci. Tak mi dopomóż Panie Boże Wszechmogący, w Trójcy Jedyny, i wszyscy święci”"17. Nawiązując do tego wątku kanoniści wskazują, iż nie można ich zastępować w przypadku, gdy nupturienci mogą mówić, przez inne znaki, takie jak: np. uścisk dłoni, czy nałożenie obrączek ${ }^{18}$. Zdaniem Bersiniego, z prawa naturalnego wprawdzie wystarczyłoby, aby wyrażono konsens w jakikolwiek sposób. Ustawodawca jednak z prawa pozytywnego domaga się, aby był on wyrażony za pomocą sposobu ściśle określonego przez prawo. Nie idzie zatem o jakiekolwiek słowa, lecz o słowa adekwatne do wydarzenia zawierania związku małżeńskiego ${ }^{19}$. Wyjaśniając tę kwestię Stefan Biskupski podkreślił, iż

\footnotetext{
16 Por. Słowo: w: L. Drabik, A. Kubiak-Sokó , E. Sobol, L. Wiśniakowska (red.) Słownik języka polskiego PWN, red., Warszawa 2014, s. 927.

17 Zob. Obrzędy sakramentu małżeństwa dostosowane do zwyczajów diecezji polskich, Katowice 1973, s. 31.

18 Por. F. Bersini, Il diritto canonico..., dz. cyt., s. 138.

19 Por. TAmże; G. Boni, La manifestazione..., dz. cyt., s. 606.
} 
słowa te „muszą jasno określać przedmiot zgody małżeńskiej”" ${ }^{\text {. Stąd }}$ też, jak pisał Petrus Gasparri, nie można posługiwać się słowami wieloznacznymi, lecz jednoznacznymi, umożliwiającymi świadkom potwierdzenie faktu zawarcia małżeństwa ${ }^{21}$. Poza tym, nie powinny one odnosić się do przyszłości, ale do samego momentu zawierania małżeństwa $^{22}$. Należy też zauważyć, iż w kan. $88 \$ 2 \mathrm{CIC/17}$ ujęto tę kwestię precyzyjniej stanowiąc: „Narzeczeni zgodę małżeńską wyrażają słowami, jeżeli mogą mówić, nie godzi się im używać równoznacznych znaków".

W obecnie obowiązującym porządku prawnym nie można zawrzeć małżeńst wa listownie, przez telefon, czy też za pośrednictwem środków społecznego przekazu ${ }^{23}$. Poruszając ten problem Viladrich napisał, iż niedopuszczalne jest „[...] gdy równoczesna i osobista obecność zostaje zastąpiona i dokonana za pośrednictwem jakiegokolwiek nośnika, które nie jest bezpośrednio słowem"24. Historycznie w prawie kościelnym przez długi czas zezwalano na zawarcie związku pomiędzy nieobecnymi; wystarczała bowiem moralna obecność. Nie wykluczano listownej możliwości zawarcia małżeństwa ${ }^{25}$.

W tym kontekście powstaje pytanie o ratio legis kan. $1104 \$ 2 \mathrm{KPK}$. Omawiając ten problem Geralinda Boni zwróciła uwagę, iż w tej kwestii w doktrynie współczesnej nie występuje zgodność opinii w tej kwestii. Jedna grupa kanonistów twierdzi, iż taki sposób wyrażenia konsensu ma ułatwić percepcję wydarzenia świadkowi kwalifikowanemu (A. Bertola); inni natomiast uważają, iż takie rozwiązanie

20 Zob. S. Biskupski, Prawo małżeńskie Kościoła Rzymskokatolickiego, Warszawa 1956, s. 296.

21 Por. P. Gasparri, Tractatus canonicus de matrimonio, t. 1., Typis Polyglotis Vatinanis 1932, s. 68.

22 Por. TAMżE, s. 67.

23 Por. P. M. Andreini, De matrimonio, Bologna 1998, s. 219; P. J. Viladrich, Konsens małżeński, dz. cyt., s. 456-457; T. PAwluk, Prawo kanoniczne według Kodeksu Jana Pawła II, t. 3, Olsztyn 1984, s. 170; W. Góralski, Kościelne prawo małżeńskie, Warszawa 2006, s. 218.

24 Por. P. J. Viladrich, Konsens małżeński, dz. cyt., s. 457.

25 Por. T. Pawluk, Prawo kanoniczne..., dz. cyt., s. 170. 
ma chronić kontrahentów przez zawarciem związku pod wpływem przymusu i bojaźni (A. Vermeersch, P. A. Bosch) ${ }^{26}$.

Na gruncie kanonistycznym w wykładni kan. $1104 \$ 2$ KPK niezwykle istotna jest też odpowiedź na kolejne pytanie: Czy wymóg, o którym mowa jest wymagany do ważności, czy też do godziwości? Innymi słowy, idzie o odpowiedź na pytanie: Czy zapis tej regulacji ma walor ustawy unieważniającej (kan. $10 \mathrm{KPK})$ ?

Komentując kan. $88 \$ 2$ CIC/17 Gasparri i Biskupski wskazali, iż historycznie myśl doktrynalna w tej kwestii ewoluowała. W prawie dawnym bowiem nie istniała zgodność poglądów kanonistów w tym, czy małżeństwo należało zawrzeć posługując się ściśle określonymi słowami, czy też można byłoby to uczynić przy pomocy jednoznacznych znaków? Większość autorów skłaniała się ku tezie, iż użycie słów było wymagane do godziwości, nie zaś do ważności. Tak utrzymywał papież Innocenty III w „De sponsalibus et matrimonio”. Pogląd tego wybitnego średniowiecznego kanonisty w decydujący sposób wpłynął na późniejsze rozwiązania w tej materii ${ }^{27}$.

Według współczesnych komentatorów, interesujący nas wymóg wymagany jest jedynie do godziwości; do ważności natomiast konieczne jest wyrażenie zgody poprzez jakieś równoznaczne znaki ${ }^{28}$. W tym wypadku istotne jest bowiem, jak pisze Chiappetta, aby udział nupturientów miał charakter aktywny, ponieważ postawa pasywna nie wywiera skuteczności prawnej ${ }^{29}$. Potwierdzenie tej tezy znajdujemy w wyroku c. Grazioli z 10 lipca 1939 roku. W części in iure tego rotalnego rozstrzygnięcia ponens podkreślił z całym naciskiem, iż

\footnotetext{
26 Por. G. Boni, La manifestazione..., dz. cyt., s. 607.

27 Por. P. GASPARri, Tractatus..., dz. cyt., s. 67; S. Biskupski, Prawo małżeńskie..., dz. cyt., s. 296.

28 Por. P. J. Viladrich, Konsens małżeński, dz. cyt., s. 457; F. Aznar Gíl, Derecho matrimonial..., dz. cyt., s. 265; R. Sевотт, Das neue..., dz. cyt., s. 106; J. Fornés, Derecho matrimonial..., dz. cyt., s. 142; F. Bersini, Il diritto canonico..., dz. cyt., s. 138 .

29 Por. L. Chinppetta, Il matrimonio.., dz. cyt., s. 256.
} 
jeśli nupturient nie odpowiadałby na pytania proboszcza, wówczas małżeństwo byłoby nieważne ${ }^{30}$.

Koherentny, z dyspozycją kan. $1104 \$ 2 \mathrm{KPK}$, jest też zapis kan. $837 \$ 1$ KKKW, zgodnie z którym „Do ważnego i godziwego zawarcia małżeństwa konieczne jest, aby strony były równocześnie obecne i wyraziły zgodę małżeńską". Analizując treść tej regulacji nie trudno spostrzec, iż ustawodawca nie mówi w niej wyraźnie o konieczności zawarcia małżeństwa słowami; mówi jedynie o konieczności wyrażenia zgody małżeńskiej. Odnosząc się do tego pryncypium Kevin Schembri napisał, iż w tym porządku prawnym małżeński konsens jest nie tylko postrzegany jako komponent konstytutywny sakramentalności małżeństwa, ale także jako konieczny warunek jego ważności ${ }^{31}$.

Interpretując kan. $837 \$ 1$ KKKW Joseph Prader zwrócił uwagę, iż jego zapis jest nieco odmienny od zapisu kan. $1104 \$ 2 \mathrm{KPK}$, ponieważ w Kościołach Wschodnich konsens nie jest wyrażany słowami podczas rytu celebracji małżeństwa, ale wola zawarcia związku albo jest stwierdzana przez kapłana przed rozpoczęciem rytu, albo też jej wyrażanie uzyskuje skuteczność prawną poprzez znaki lub ryty symboliczne $^{32}$. Inną natomiast argumentację podał Dimitros Salachas, mianowicie, zauważył on, że w niektórych rytach wschodnich nie przyzwala się na wyrażenie woli przy pomocy słów, albowiem nupturienci powinni wyrazić zgodę za pomocą gestów, bądź też rytów specjalnych. Systemowe założenie generalne w tej materii polega na tym, że do ważności konsens musi być wyrażony w sferze zewnętrznej ${ }^{33}$.

\footnotetext{
30 Por. Dec. c. Grazioli z 10 VII 1939, SRRD, t. 31, s. 436.

31 Por. K. Schembri, Oikonomia, Divorce and Remarriage in the Eastern Ortodox Tradition, Roma 2017, s. 58.

32 Por. J. Prader, Il matrimonio in oriente e in occidente, Roma 2003, s. 250: „[...] Infatti secondo la genuina tradizione delle Chiese orientali, il consenso non viene espresso con parole durante il rito della celebrazione del matrimonio, perché la volontà concorde di unirsi in matrimonio, o è constata dal sacerdote prima di iniziare il rito, o la sua manifestazione, sempre necessria, è efettuata con segni o riti simbolici”.

33 Por. D. Salachas, Commento al. can. 837 CCEO, dz. cyt., s. 717.
} 
Z przeprowadzonej analizy wynika, iż w kan. $837 \$ 1$ KKKW nie uwydatniono w sposób wyraźny wymogu zawarcia związku małżeńskiego przy użyciu ściśle określonych słów. Z tego zapisu można wysunąć wniosek, iż w legislacji wschodniej, podobnie, jak w legislacji zachodniej wymóg ten jest wymagany jedynie do godziwości.

Wracając do zasadniczego wątku tych rozważań związanego z interpretacją kan. $1104 \$ 2$ KPK pragniemy przywołać myśl Tadeusz Pawluka, który wyjaśniając interesujący nas zapis normatywny napisał: „Nowe prawo nie stanowi wyraźnie, że wyrażenie zgody małżeńskiej słowami przez tych, którzy mogą mówić jest tylko wymagane do godziwości zgody małżeńskiej. Stanowiły o tym przepisy prawa dekretałowego i poprzedniego Kodeksu. Nie ma podstaw do twierdzenia, że obecnie jest inaczej. Dlatego małżeństwo byłoby ważnie zawarte gdyby strona w czasie ślubu pod wpływem silnego wrażenia nie mogąc wydobyć głosu tylko skinieniem głowy wyraziła zgodę małżeńską”34. Podobną opinię wyraził Vildrich pisząc: „Odnośnie do kan. $1104 \$ 2$ powinniśmy rozróżnić pomiędzy ważnością a godziwością. W ścisłym sensie do ważności wyrażenia zgody małżeńskiej wystarczy, by dokonała się ona ze strony nupturientów poprzez te znaki, które uzewnętrzniają w jednoznacznej formie wspólna wolę zawarcia matżeństwa, a nie jakiejś innej relacji. Konkretnie ważnym znakiem jest ten znak, który jest zdolny jednoznacznie wyrazić według stosownych form kulturowych nupturientów - że oboje pozytywnie chcą, oraz że tym czego chcą jest małżeństwo, a nie coś innego. Do godziwości nupturienci powinni wyrazić własnym słowem - wyrażenie ustne własną zgodę, przy czym nie uznaje się za godziwe posłużenie się innymi równoznacznymi znakami, chyba że nupturient nie może mówić”35.

34 Por. T. Pawluk, Prawo kanoniczne..., dz. cyt., s. 170.

35 Zob. P. J. Viladrich, Konsens małżeński, dz. cyt., s. 457. 


\subsection{Wyjątek od zasady generalnej}

Jak nadmieniono, w analizowanym kan. $1104 \$ 2$ KPK skodyfikowano także wyjątek od zasady generalnej stanowiąc, że w sytuacji w której nupturient nie mógłby mówić, wówczas mógłby wyrazić zgodę równoznacznymi znakami. Odnosząc się do tego paragrafu Bersini podkreślił, iż w tym wypadku nie chodzi wyłącznie o niemożliwość fizyczną, ale w grę wchodzi również niemożliwość moralna. W jego przekonaniu, każda przyczyna poważna uprawnia do posłużenia się innymi znakami, ale tylko takimi, które w sposób jednoznaczny wskazywałyby na wolę zawarcia związku ${ }^{36}$. Znaki te bowiem dla świadków powinny być jednoznaczne ${ }^{37}$. W literaturze wskazuje się, iż można byłoby tego dokonać np. poprzez wymianę obrączek, czy też wzajemnym uściskiem dłoni ${ }^{38}$. Stąd też nie spełnia tego warunku milczenie ${ }^{39}$. Jest tak dlatego, ponieważ nie jest ono zewnętrznym znakiem ${ }^{40}$. W takiej sytuacji nie można przecież zweryfikować faktu, czy strony chcą małżeństwa.

Zajmujący się tym zagadnieniem kanoniści także piszą, iż omawiana hipoteza dotyczy również możliwości zawarcia małżeństwa przez tłumacza, w przypadku gdy kontrahenci nie znają języka (kan. $1106 \mathrm{KPK})^{41}$. W tym wypadku niekonieczne jest uzyskanie zezwolenia ordynariusza miejsca ${ }^{42}$.

\footnotetext{
36 Por. F. Bersini, Il diritto canonico..., dz. cyt., s. 138.

37 Por. T. Pawluk, Prawo kanoniczne..., dz. cyt., s. 170; P. J. Viladrich, Konsens małżeński, dz. cyt., s. 457.

38 Por. J. Prader, Il matrimonio..., dz. cyt., s. 250; R. Althaus, J. Prader, J.F. Reinhard, Das kirchiliches Eherecht..., dz. cyt., s. 132.

39 Por. F. Bersini, Il diritto canonico..., dz. cyt., s. 139.

40 Por. P. J. Viladrich, Konsens małżński, dz. cyt., s. 457; L. SABbarese, Il matrimonio canonico..., dz. cyt., s. 289.

41 Por. F. Bersini, Il diritto canonico..., dz. cyt., s. 138.

42 Por. T. PAwluk, Prawo kanoniczne..., s. 171.
} 


\section{Zakończenie}

Z przeprowadzonych analiz wynika, iż w obowiązującym porządku prawnym do ważności obydwoje nupturienci powinni być równocześnie obecni, bądź też mogą zawrzeć związek przez pełnomocnika (pełnomocników).

Z natury rzeczy do ważności nie wystarcza wyrażenie małżeńskiego konsensu w sferze wewnętrznej; konieczne jest bowiem jego uzewnętrznienie ze względu na potrzebę społecznej weryfikacji ${ }^{43}$ oraz ze względu na godność drugiej osoby, której nupturient pragnie ofiarować samego siebie ${ }^{44}$.

Kanoniści są zgodni co do tego, iż z prawa naturalnego zgoda małżeńska w sferze zewnętrznej może zostać wyrażona w jakikolwiek sposób. W prawie kościelnym prawodawca jednak nie przyzwolił na taką dowolność, ponieważ określił sposób wyrażenia zgody małżeńskiej, o czym świadczy zapis 1104 \$1- 2 KPK. W sytuacji zwyczajnej, gdy nupturienci mogą mówić powinni zawrzeć małżeństwo słowami. Przy czym spełnienie tego wymogu nie jest wymagane do ważności, ale do godziwości aktu. W uwarunkowaniach nadzwyczajnych jednak, a więc w sytuacji gdy przynajmniej jedna ze stron nie mogłaby mówić, wówczas mogłaby ona wyrazić konsens równoznacznymi znakami. Wymogów, o których mowa nie spełnia milczenie. W tej hipotezie bowiem wola zachowuje się inercyjnie. W następstwie czego akt prawny, jakim jest zgoda małżeńska w systemie, nie uzyskuje skuteczności.

43 Por. W. Góralski, Kościelne prawo..., dz. cyt., s. 218.

44 Por. L. Sabbarese, Il matrimonio..., dz. cyt., s. 288. 


\section{The Form of Expressing Matrimonial Consent Specified in Can. $1104 \$ 1-2$ CIC}

\section{Summary}

The analyses of the current legal order show that for a marriage to become contracted validly the contracting parties need to be present together or may enter into marriage by proxy (proxies).

Naturally, for a marriage to be valid it is insufficient to express matrimonial consent in the internal sphere only; it is necessary to externalize the consent with the aim of its social verification ${ }^{45}$ but also because of the dignity of the other party to whom a nupturient is willing to give himself.

Canonists agree that according to the natural law matrimonial consent in its external sphere could be expressed in any possible way. However, in the ecclesiastical order the legislator did not allow this kind of latitude and specified the forms of expression of matrimonial consent (as discussed in can. $1104 \$ 1-2$ CIC). In an ordinary situation, if both nupturients can speak, they should contract a marriage in words although meeting this requirement is not necessary for the validity but rather for the fairness of the act. However, in extraordinary conditions, when at least one person cannot speak, it is possible to express one's consent through equivalent signs. Silence nonetheless does not meet the criteria discussed here since in this hypothesis one's will remains inertial and, as a result, a legal act does not attain effectivity in the system.

Key words: matrimonial consent, form, word, equivalent signs.

45 See: W. Góralski, Kościelne prawo..., op. cit., p. 218. 